\title{
Application of Seafloor Mapping Technology for Search and Rescue: AirAsia QZ8501 Case Study
}

\author{
Rahadian $^{1 *}$, Muhammad Irfan ${ }^{1}$, Athur Yordan $^{1}$, Taufan Wiguna ${ }^{1}$, Ouzani Bachir ${ }^{2}$ \\ ${ }^{1}$ Technology Center for Marine Survey, Agency for the Assessment and Application of Technology, \\ Jl. M.H. Thamrin No.8, Jakarta 14320, Indonesia \\ ${ }^{2}$ PT. Offshore Works Indonesia, Jl. Mahakam 1 No 11 B Kramat Pela, \\ Kebayoran Baru, Jakarta 12130, Indonesia
}

Received: 22 June 2015, Revised: 1 Aughust 2015, Accepted: 17 December 2015

\begin{abstract}
Seafloor mapping shows size, position, and depth of morphology and any objects at seafloor. Therefore, these technologies can be used to search and rescue (SAR) which are applied when AirAsia QZ8501 was missing at southern Karimata Strait using three vessels, RV. Baruna Jaya I, MV. Java Imperia, and KN. Trisula. Seafloor mapping technologies that applied were (i) multibeam echosounder system (MBES), (ii) side scan sonar (SSS), (iii) magnetometer (MM), (iv) autonomous underwater vehicle (AUV), (v) pinger locator (PL), (vi) underwater remotely operated vehicles (ROV). MBES, SSS, AUV, and USBL use acoustic wave that transmitted by transducer to seafloor then it back to reciever. Indirectly, MBES and SSS generate 3D image based on acoustics signal according to sound propagation and its travelling time in sea from transducer to receiver. MBES and SSS transmit acoustic wave with frequency $180 \mathrm{kHz}$ for MBES and dual-frequency $(120 \mathrm{kHz}$ and $420 \mathrm{kHz})$ for SSS. AUV that attached SSS working with frequency $600 / 1600$ $\mathrm{kHz}$. USBL that used as pinger locator transmit acoustic wave with same frequency as blackbock which known using $37.5 \mathrm{kHz}$. USBL inform distance between transducer to blackbox, so that the position of blackbock can be determined by triangulation method. MBES and SSS on KR. Baruna Jaya I detect suspect anomaly with height about 3 meters. SSS that installed on AUV and operated on KN Trisula detect an object looks like human body. Triangulation method was done on MV. Java Imperia has found blackbox position.
\end{abstract}

Keywords: seafloor, mapping, search and rescue (SAR), AirAsia QZ8501

\section{INTRODUCTION}

Seafloor mapping technologies are scientific instruments that used to get depth data then generated to morphology in 3D image through acquisition and data processing. These technologies usually applied to marine research and maritime industry. however, according to their ability, they can be used to find objects at seafloor. They can be applied to search and rescue (SAR) in sea.

Technology Center for Marine Survey Agency for the Assessment and Application of Technology, known as Balai Teknologi Survei Kelautan - Badan Pengkajian dan Penerapan Teknologi (BPPT), has applied seafloor mapping technology for search and rescue. Some previous SAR operation that had been done by BPPT are KM

\footnotetext{
Corresponding author.

E-mail address: rahadian@bppt.go.id
}

Gurita that sunk at Sabang in 1996, KM Senopati Nusantara and AdamAir plane that sunk at Makassar Strait in 2007, search for Kukar Bridge ruins in 2011, and found KM Bahuga Jaya that sunk at Sunda Strait in 2012 [1]. Accordingly, Head of BPPT (Unggul Priyanto) was ordered directly by President RI (Joko Widodo) to give solution in technology and investigation for AirAsia QZ8501 SAR that disappear in Karimata Strait [2].

Technologies that used for AirAsia QZ8501 search and rescue are (Fig.1): (i) multibeam echosounder (MBES), (ii) side scan sonar (SSS), (iii) magnetometer (MM), (iv) autonomous underwater vehicle (AUV), (v) pinger locator (PL), (vi) underwater remotely operated vehicles (ROV). That instruments, except MM and ROV, use acoustic signal for data acquisition. MM and ROV is used to object verification on seafloor and PL is used to determine blackbock distance and position. 
This paper will discuss about seafloor mapping technologies that use acoustic for SAR purpose.

\section{THEORY AND EXPERIMENTAL METHOD}

Multibeam measure time travel acoustic wave pulse from transducer to seafloor then receiver. Sea depth measurement using this formula

$$
D=1 / 2(c \cdot \Delta t)
$$

where $D$ is sea depth, $c$ is sound speed in sea and, $\Delta t$ is wave time travel from transducer to seafloor and back to receiver [3] [4].

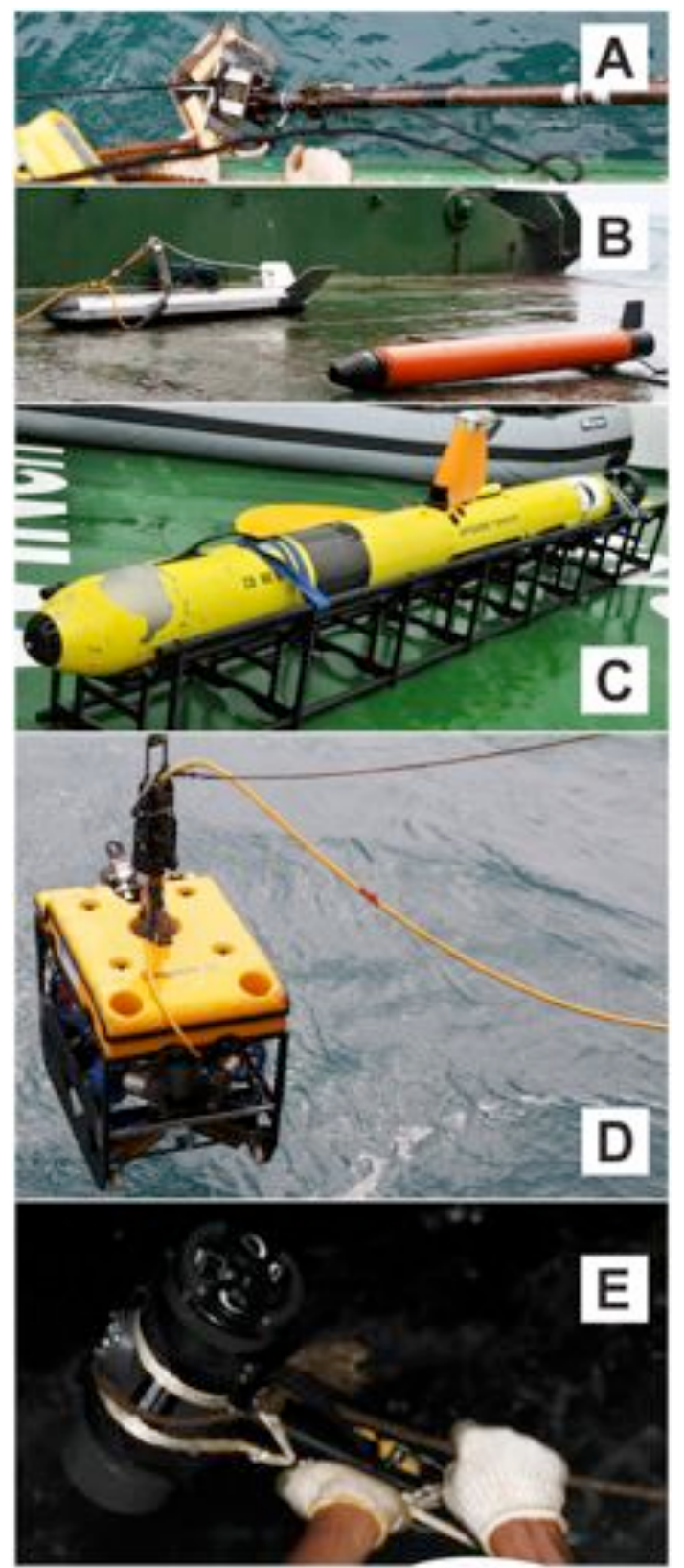

Fig. 1. (A) Multibeam Echosounder; (B) Left: Side Scan Sonar, Right: Magnetometer; (C) Autonomous Underwater Vehicle; (D) Remotely Operated Vehicles (ROV); (E) Pinger Locator
Multibeam consist of 126 beams and range between beam is $1.5^{\circ}$, so the maximum sweep of it is $153^{\circ}$ [5]. Beam generate horizontal profile and its wide equivalent to eight times of sea depth. Multibeam resolution depend on distance between beam interval that can be setting directly in instrument and ship speed (Fig.2). In this case, an object suspect that interpreted as airplane body of AirAsia QZ8501 founded by MBES that operated on RV. Baruna Jaya I.

SSS use narrow beam for horizontal field (Fig. 3) to get high resolution through seafloor area. SSS applied acoustic backscatter to distinguish the appearance of morphology and object on seafloor. SSS reflector shows object characteristics on seafloor which if it is a metal or boulder will show strong reflector and soft sediment shows weak reflector [5]. In this case, SSS obtained from towed SSS on RV. Baruna Jaya I and SSS attached in AUV that operated on MV. Java Imperia and KN. Trisula.

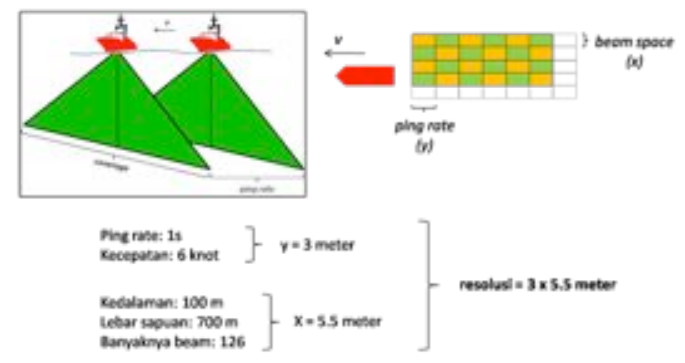

Fig. 2. Multibeam resolution

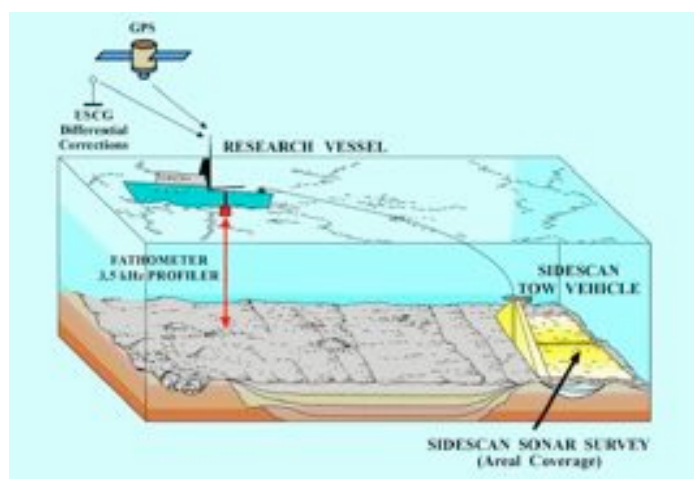

Fig. 3. Side Scan Sonar Towing System

AUV has some module that can be plug and remove according to mapping survey aim. In this case, AUV consist of Swath Bathymetry and Side Scan Sonar module. Side scan sonar that applied is Edgetech 2205 with frequency $600 / 1600 \mathrm{kHz}$ and Swath Bathymetry that used is GeoSwath Plus interferometric sonar with frequency $500 \mathrm{kHz}$. 
Triangulation method is a process to find coordinate and depth of an object under sea level based on three difference measurement location. The measurement of each location will result the distance between PL and blackbox. The blackbox coordinate and depth were got by angulate according to three measurement locations where each location will result measurement coordinate and distance between PL and blackbox. The communication between PL and blackbox must be done in same frequency which is $37.5 \mathrm{kHz}$ [6].

\section{RESULTS AND DISCUSSION}

AirAsia QZ8501 SAR get some suspects. Multibeam data shows a suspect as an object with height about 3 meters that showed by beam line that follow the shape of object (Fig.4). After that interpretation, magnetometer is applied to verify metal object. ROV was used to direct observation through underwater camera.

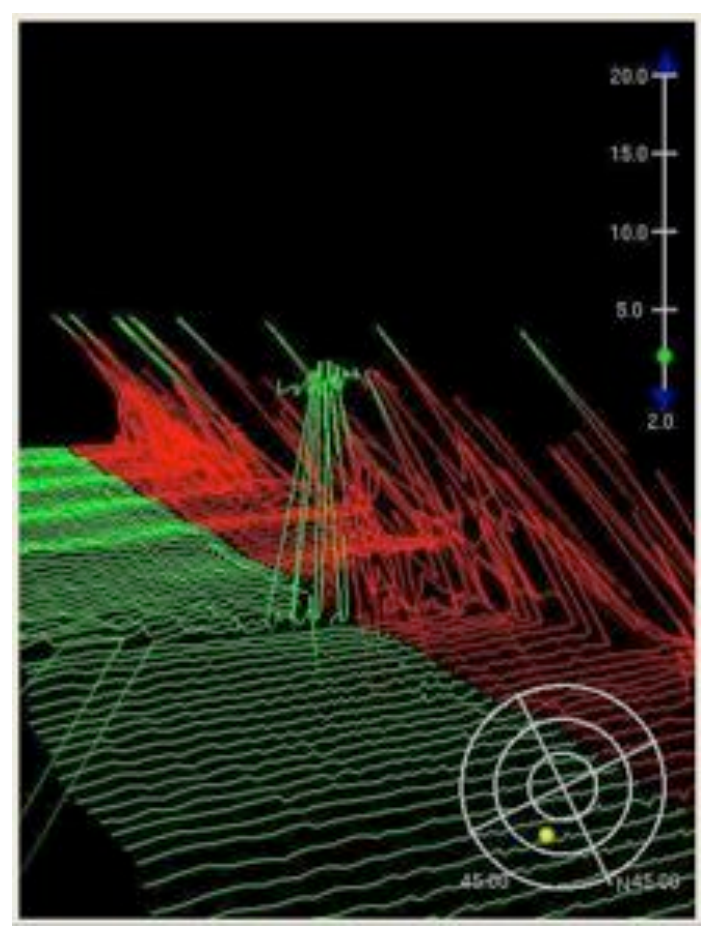

Fig. 4. An object as suspect of airplane body

Blackbox searching rely to pinger locator (PL). Based triangulation method obtainable to get blackbox coordinate then verified by MB and SSS. Multibeam (Fig.5) and side scan sonar (Fig.6) show an object on seafloor and then verified by diver.

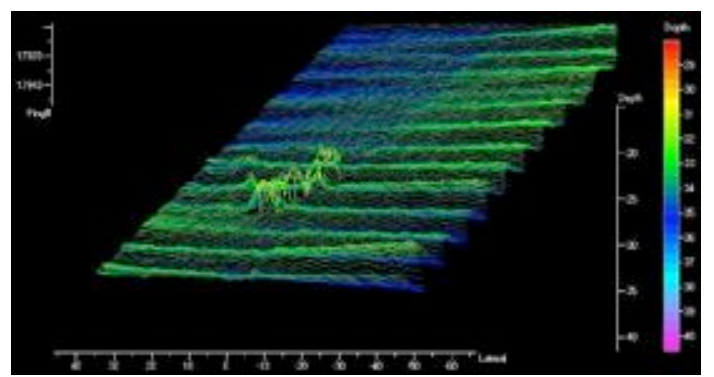

Fig. 5. Suspect that interpreted as part of airplane body which is blackbox ping signal located

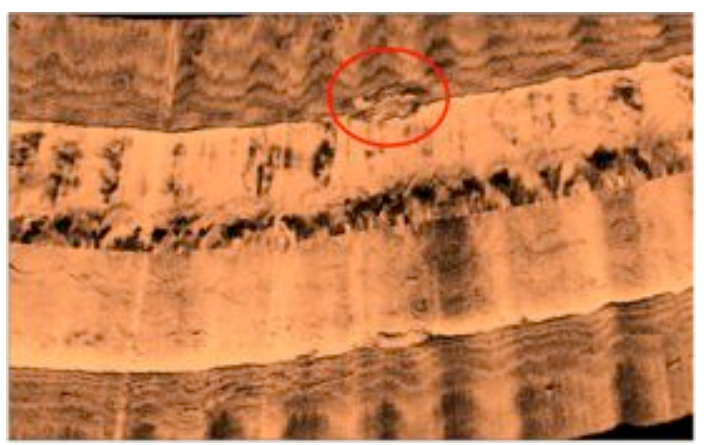

Fig. 6. Side scan sonar result that taken on RV. Baruna Jaya I shows a suspect interpreted as blackbock

AUV that operated by Java Offshore team does multibeam and side scan sonar acquisition. The result is side scan sonar data shoe an object similar to human body (Fig.7). This object immediately verified by diver team.

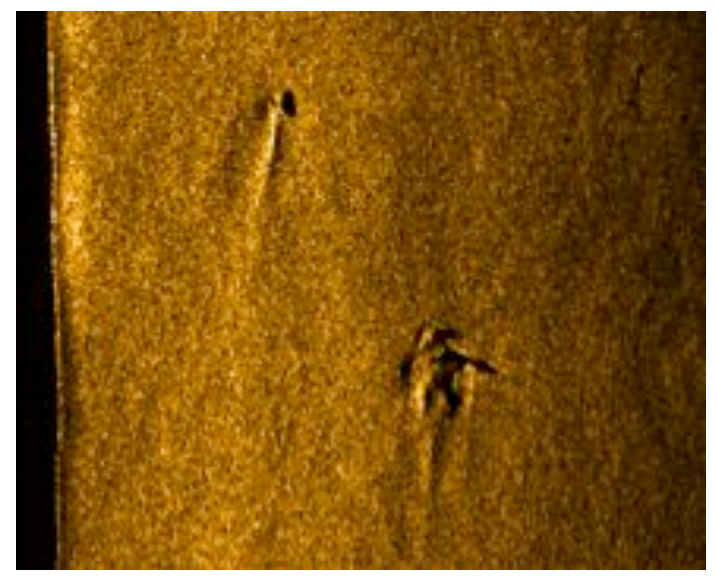

Fig. 7. Side scan sonar result taken by AUV

Seafloor mapping technologies are used to get seafloor morphology and represent object on seafloor. Each instrument has advantages and disadvantages in results so that in SAR that has to be done quickly, it used simultaneously and without data processing. Data interpretation from unprocessed data must be done by experts. 


\section{CONCLUSION}

Seafloor mapping technology can be used to search and rescue for objects on seafloor. MB and SSS are used to get shape of the objects, MM is used to metal object verification, AUV is used to get high resolution seafloor image, ROV is used to direct observation, and PL is used to measure distance between transducer and blackbox and determine the blackbox location.

\section{ACKNOWLEDGMENT}

The authors thanks to SAR team for their cooperation which are KR. Baruna Jaya I, MV. Java Imperia, dan KN. Trisula. Thanks to BASARNAS team and TNI AL diver team. Multibeam and side scan sonar data for blackbox suspect was taken by KR. Baruna Jaya I that owned by Technology Center for Marine Survey, Agency for the Assessment and Application of Technology (BPPT). Side scan sonar data for victim was taken by Java Offshore/OWI team using their AUV which collaboration with KN. Trisula. Magnetometer that used to metal verification owned by Marine Geological Institute. ROV that used to suspect verification owned by PT. Patra Dinamika. Thanks to Coordinating Minister of Maritime Affairs (Indroyono Soesilo), Deputy Chairman for Natural Resource Development Technology BPPT, Head and Management of Technology Center for Marine Survey BPPT, current modelling (Nani Hendriyanti and team.), Imam Mudita as daily person in charge of PUSKODAL BPPT, Anan Fauzi for the pictures. Thanks to BMKG for weather forecast.

\section{REFERENCES}

[1] BPPT, "Kapal Canggih BPPT Bantu Cari Pesawat AirAsia QZ-8501", 2014, URL http://bppt.go.id/index.php/teknologi-sumber daya-alam-dan-kebencanaan/2129-kapalcanggih-bppt-bantu-cari-pesawat-airasia-qz8501 [retrieved June 15th 2015]

[2] BPPT, "Kepala BPPT: Baruna Jaya I Diharapkan Tidak Lama Lagi Temukan Reruntuhan Pesawat Air Asia QZ8501“, 2014, URL http://bppt.go.id/index.php/layananinformasi-publik/2139-kepala-bppt-barunajaya-i-diharapkan-tidak-lama-lagi-temukanreruntuhan-pesawat-air-asia-qz8501 [retrieved June 15th 2015]
[3] Baidhuri Purna Edi, "Aplikasi Instrumen Akustik Multibeam dan Side Scan Sonardi perairan Sekitar Teluk Mandar dan Selat Makassar", Skripsi Sarjana, Institut Pertanian Bogor, 2009, p. 68

[4] L-3 Communications SeaBeam Instruments, "Multibeam Sonar Theory of Operation", p. 102, URL http://www.ldeo. columbia.edu/res/pi/MB-System/sonar function/SeaBeamMultibeamTheoryOperation. pdf [retrieved June 15th 2015]

[5] L-3 Communications ELAC Nautik GmbH, "SeaBeam 1050 / 1055: Medium Water Multibeam Systems", URL http://www.elacnautik.de/_uploads/images/pdf/1_L3_ELAC_N autik_SB_1050_1055.pdf [retrieved June 15 th 2015]

[6] BPPT, "Kotak Hitam Air Asia Ditemukan Karena Berfrekuensi 37,5 khz", 2015, URL http://bppt.go.id/index.php/layanan-infor masipublik/2148-kotak-hitam-air-asia-ditemukankarena-berfrekuensi-37-5-khz [retrieved June 15th 2015] 